\title{
The Design of SOA-based Applications for Electronic Medical Records in DKI Jakarta
}

\author{
Refito Ilham $^{1}$, Satria Wisesa ${ }^{2}$, Wiza Teguh ${ }^{3}$, Yohannes Kurniawan ${ }^{4}$ \\ ${ }^{1,2,3}$ Information Systems Management Department, BINUS Graduate Program - Master of Information Systems \\ Management, Bina Nusantara University, Jakarta 11480 \\ ${ }^{4}$ Information Systems Department, School of Information Systems, Bina Nusantara University, Jakarta, \\ Indonesia, 11480 \\ ${ }^{1}$ refito.wicaksono001@binus.ac.id, ${ }^{2}$ wiza.teguh@binus.ac.id, ${ }^{3}$ satria.wisesa@binus.ac.id, \\ 4ykurniawan@binus.edu
}

\begin{abstract}
The Hospital is public health care institutions. The services and actions will affect the patient's condition and comfort. all of that needs support from information systems that support business processes. The Hospital require Information systems that support for daily activity. Consider to Applying Enterprise Application Integration (EAI) is to connect various databases from other systems. Then, using EAI based on SOA, data sharing can be done in real time and unlimited business processes between applications and data sources that are interconnected.
\end{abstract}

Key words: EAI Based on SOA, EMR, Industry 4.0 in Health Institution, SOA.

\section{INTRODUCTION}

In the era of the industrial revolution 4.0, only institutions, companies and health workers who are innovative and responsive to changes in technological developments will survive and continue to exist in society ", or in other words, it requires the development of data processing capabilities and patient management based on existing data , " said Public health expert, Prof. Dr. Ali Ghufron Mukti, MSC, to reporters, in Jakarta, Monday (5/11), In line with that, One of the youngest Professors at FKUI and a pioneer of reproductive medicine innovation in the era of disruption, Prof. Dr. Dr. Budi Wiweko, SpOG (K), MPH considers the electronic health record (EHR) is also an important factor to support the role of "Big Data" in the current era of precision medicine. He said that What is recorded in the electronic health record is not only clinical data but also genomic data [1]. On the other hand, Big data is data received from various directions with different objects and bigger capacity than ordinary data used by Normal computers [16]. In addition, Big data can also be used in producing new product development.

Based on above condition, every Health Facility should have held a Digital Medical Record, known as an Electronic Medical Record (EMR), but in reality the implementation of EMR in Indonesian hospitals is still not much, due to many obstacles, so the implementation of EMR in Indonesia has not yet developed, among others, high initial costs, human resources and legal rules that are still poorly understood [2]. Technologically, EMR is already very possible, the problem is the legal aspect of administering EMR, considering the Medical Record is Medical Record is a systematic collection of electronic patient-based health information that is connected and integrated with information systems (Laws and regulation of Ministry of health (Kementrian Kesehatan) in Article 13 paragraph (1) b number 269 in 2008 concerning Medical Records) [3].

The medical record explains that the file contains records and documents about the patient's identity, examination, treatment, other medical measures at the health service facilities for outpatient, inpatient treatment, either managed by the government or private. Contents of medical records are confidential which must be maintained by health workers and medical records officers [2]. This is done to facilitate the recording and storage of patient health data.

Medical Records were initially carried out conventionally, namely through a piece of paper, but entering the 21 st century marked by information technology, the use of conventional Medical Records is not enough. Medical Records must be implemented with technological, it means to make it more support and facilitate health services to patients. In accordance with the program planned by the government based on the basis of Health Development, and to realize the Healthy Indonesia Vision of 2025, the Health Development mission was established, namely to improve and utilize health resources including human health resources, health 
financing, as well as pharmaceutical preparations and medical devices. Health resources include the mastery of health / medical science and technology, as well as data and information that are increasingly important in their role. One of the data and information (information technology) about health in accordance with the flow of globalization is the Electronic Medical Record (hereinafter referred to as EMR) [4].

In line with its development, EMR has become the heart of information in hospital information systems. However, health workers and managers of health service facilities are still hesitant to use them because there are no laws and regulations specifically regulating their use. Since the issuance of the Information and Electronic Transaction Law and regulation (UU ITE) Number 11 in 2008 has provided answers to existing doubts. The ITE Law has provided opportunities for EMR implementation [5].

In the ITE Law there is no known EMR, the ITE Law only recognizes: Electronic Documents, namely any Electronic Information that is created, transmitted, sent, received, or stored in analog, digital, electromagnetic, optical, or the like, which can be seen, displayed, and / or be heard through a Computer or Electronic System, including but not limited to writing, sound, images, maps, designs, photographs or the like, letters, signs, numbers, Access Codes, symbols or perforations that have meaning or meaning or can be understood by people who is able to understand it [2].

The Electronic Health Record (EHR) experiences several obstacles, namely the interrelationship between the government system and the hospital system, the problem of leaking patient privacy data, and the suitability of the arrangement of the system with the main purpose of the EHR itself [6].

Important aspects of the organization of medical records are authentication and confidentiality. On EMR: authentication is done by identifying the signature of the EMR maker, while confidentiality is done by storing the EMR file in a special room that only hospital personnel can enter. Whereas for EMR, authentication is done using a cryptographic technique known as Electronic Signature (UU TTE) [2]. This is to prevent leakage of patient data and misuse of data by irresponsible parties.

Researcher from Journal Title A Proposition of Critical Success Factors Influencing Service Oriented Architecture (SOA) Implementation in Healthcare, Researching on Critical Success Factor (CSF) of an SOA implementation in the healthcare industry. During its development, Industries from various sectors began to realize the importance of integration. Therefore, the presence of SOA began to be considered important. SOA can bridge the existing systems in a business process to be integrated with each other. However, it is written in this paper that in reality, many organizations that have implemented SOA state that the application of SOA does not produce results as expected. To find out what causes SOA implementation is not as expected, the authors of this paper conducted a literature study on CSF from SOA, and more specifically CSF from SOA implementation in the health industry, along with case studies (Koumaditis, Themistocleous, Mantzana, \& Souliotis, 2012) [7].

Service Oriented Architecture is an information technology architecture that defines an interaction model between three main functional units, namely consumer (requestor) interacting with service providers to find services that meet their needs through searching the registry. With SOA, different applications can communicate with each other. SOA is, among others, loosely coupled coupled low interdependent components), highly interoperable (easy to operate reusable, and interoperability (can communicate between platforms) [8].

\section{LITERATURE REVIEW}

The methodology used in this journal is systematic literature review (SLR) and. As explained in Figure 1.

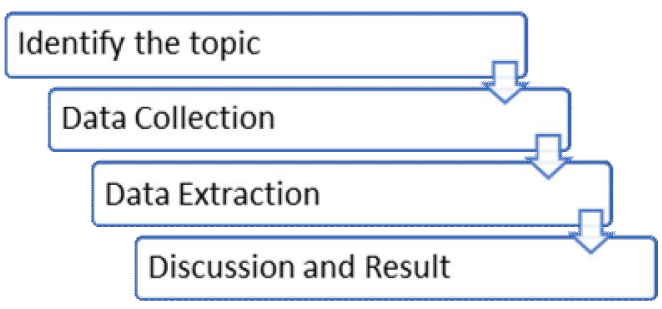

Figure 1: SLR Concept

\subsection{Current Situation in Health Industry}

First, determining the topic to discuss a problem and a phenomenon that exists today in the DKI Jakarta. Based on the phenomenon that occurs today in the world of health, Head of PT. Pertamedika - IHC, dr. Fathema Djan Rachmat Sp. B, Sp BKTV (K) in the JIMCA program at Hotel Mulia in Jakarta 29 July 2019 said that hospitals must have industry-based health services 4.0. Business entity that owned by Government $(B U M N)$ all hospitals must be trendsetters for other hospitals that will use digital concepts for their services. 78 Hospitals have used E-Medical Records. The most integrated is Pelni Hospital. Other hospitals are not optimal yet but have started paperless [9].

In addition, the world is currently in the industrial era 4.0 (4.0) where information exchange and storage are its main characteristics. Era 4.0 gets the title Big Data, because the information available is $3 \mathrm{~V}$ which is having a Volume (a large amount), Velocity (high speed of information flow), and Variety (various types of data). In this case the medical world is inseparable from this condition because of the large flow of patients from day to day, with all kinds of problems that 
require unique handling [10]. Dissemination of information using various data is felt by everyone [15].

Public health expert, Prof. Dr. Ali Ghufron Mukti when met by reporters in Jakarta on Monday (5/11), In the era of the industrial revolution 4.0, only institutions, companies and health workers who are innovative and responsive to changes in technological development will survive and continue to exist in the community, or in other words, it requires the development of data processing and patient management capabilities based on existing data [8]. Then, Data Collection and Data Extraction is the process of finding data from journals related to current problems in the world of health. Collecting journals from similar topic problems, both abroad and in Indonesia. In Data Extraction, after the data collection process, the grouping of data related to the problem and scope limitation of development or application of SOA in hospitals. The application is built using ASP. Net C \# 2.0, Oracle XE, and service-oriented architecture [11].

Therefore, based on data and information that has been mentioned, that SOA became a design to implement Electronic Medical Records (EMR) in the industry 4.0 era in hospitals. Finally, Discussion on how to implement and implement steps into real cases in hospitals in Jakarta Province and what are the obstacles.

\section{RESULT AND DISCUSSION}

\subsection{Analysis}

Analyze each business process that can be used as a service and needs to be developed. Electronic Medical Record is critical data that is needed by the hospital. Without it the medical staff can't identify patient complaints and can even disrupt business processes. Systems are often evaluated based largely on the above electronic medical records requirements and classifications of features of EMR. However, there are functional requirements to keep in mind as well. These EMR software features will help streamline workflows within your practice, between your practice and pharmacies, and between patient and care teams [12]. Some Functional requirements that support the condition of the Health industry in Jakarta Province are;

- E - Reporting

- E - Document

- Billing System Integration

- Pharmacy Integration

- Insurance Verification Integration.

- Patient Medical Information

- Scheduling

- Peer to Peer Hospitals

- Biometric and Authorization

\subsection{Identification}

There are problems that arise in the interaction between systems and other modules as follow;

- Integration and synchronization problems between modules and systems.

- Systems are interconnected and interdependence.

- Patient medical record authorization and access right.

\subsection{Electronic Medical Record Framework Design}

In this stage, Discuss SOA Framework design for Electronic Medical Record in Jakarta Province. Data dalam EMR merupakan rekaman legal dari pelayanan yang telah diberikan pada pasien dan data tersebut disimpan serta dimiliki oleh fasilitas pelayanan kesehatan. The privacy of patient data is important, for that only certain people can access it and someone who has permission from the patient. Therefore, to access each module or system requires authentication from users who have authorization rights such as passwords, and fingerprints. The architecture framework shown in figure 2.

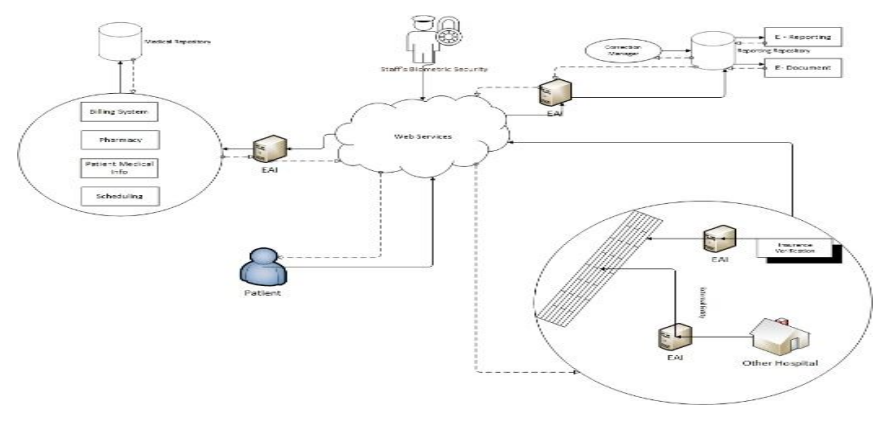

Figure 2: Framework Design

The Electronic Medical Record, designed for Jakarta, has several zone categories based on the entity's region, with an explanation below. External Entity, the purpose of this entity is to connect the internal EMR system to health institutions with insurance companies or other hospitals. The framework includes Firewall and Enterprise Application Integration (EAI) which is to connect various databases from other systems. By using EAI based on SOA, data sharing can be done in real time and unlimited business processes between applications and data sources that are interconnected between Internal Entity and External Entity. The type of EAI architecture in EMR is as a point to point, the system communicates directly with other systems [13].

In application integration, the User Interface Level method can be used, namely by using their User Interface as a common point in integration. This method is used when a system does not allow integration through the data level, application level or method level [14]. Each entity has its own EAI because it operates on a different system and requires real 
Refito Ilham et al., International Journal of Emerging Trends in Engineering Research, 8(2), February 2020, 606 - 610

time data sharing. Below are the authorization of each entity shown in table 1

Table 1 : Authentication Entity

\begin{tabular}{|c|c|c|c|c|}
\hline Entity & Create & Update & Delete & View \\
\hline Correction Manager & $\mathrm{X}$ & $\mathrm{V}$ & $\mathrm{V}$ & $\mathrm{V}$ \\
\hline Finance Adm. & $\mathrm{X}$ & $\mathrm{X}$ & $\mathrm{X}$ & $\mathrm{V}$ \\
\hline Operational Adm. & $\mathrm{V}$ & $\mathrm{V}$ & $\mathrm{V}$ & $\mathrm{V}$ \\
\hline Patient & $\mathrm{X}$ & $\mathrm{X}$ & $\mathrm{X}$ & $\mathrm{V}$ \\
\hline Pharmacist & $\mathrm{X}$ & $\mathrm{V}$ & $\mathrm{X}$ & $\mathrm{V}$ \\
\hline Doctor & $\mathrm{V}$ & $\mathrm{V}$ & $\mathrm{V}$ & $\mathrm{V}$ \\
\hline Insurance & $\mathrm{X}$ & $\mathrm{X}$ & $\mathrm{X}$ & $\mathrm{V}$ \\
\hline
\end{tabular}

o Correction Manager, someone who has authority into the EMR system for verification of every document uploaded and patient information.

o Finance Adm, someone who has the authority to make billing payments based on patient data from the EMR system.

- Operational Adm, who has authority into the EMR system to input patient data, recap patient data and documentation.

- Patient, has authority in the EMR system to view their health records, scheduling and medical information related to their complaints.

- Pharmacist, has authority into the EMR system to update information about patient data related to medicine.

- Doctor, Having the authority to be able to input, update, Create patient data into the EMR system. Because doctors know the history of patient health.

o Insurance, External entity from health agencies that have authority only see patient data in the EMR for data collection and verification purposes.

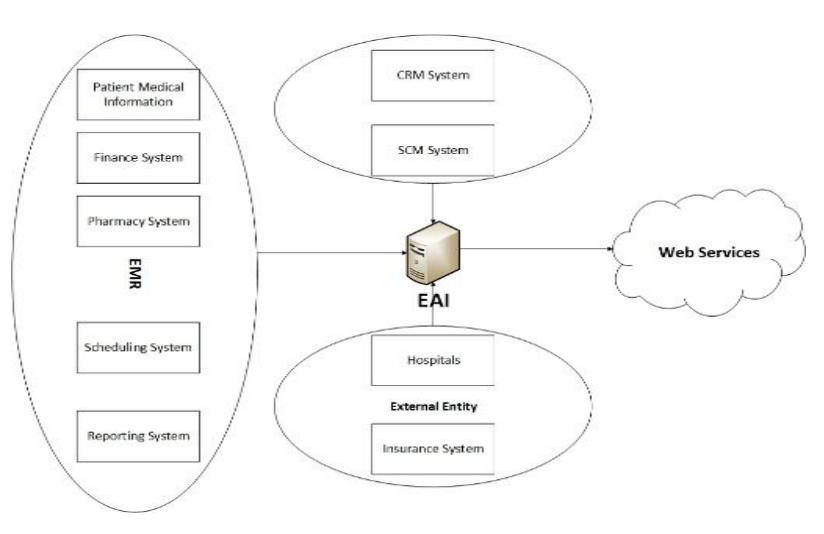

Figure 3: EAI Design

The process of data communication between systems and applications will pass through EAI. Because if the data exchange process occurs directly or directly, then when one system crashes, it will also have a direct impact on the other system. But if you use EAI, if one system crashes, it will not affect the other systems. Another advantage of EAI is that the process of developing various applications needed in a company will be faster.

\section{CONCLUSION}

Implementation of SOA in Hospital information systems for excellent service, requires large costs, with the implementation of SOA allows the development of a centralized system. So, there are many resources that can be reduced. Thus, it will reduce costs too. Excellent Service is all the best and perfect system is realized to meet the needs so that the user feels satisfied. The SOA research method divides functions into different units (services), which can be distributed through a network and combined and reused to form business applications. By using EAI based on SOA, data sharing can be done in real time and unlimited business processes between applications and data sources that are interconnected between Internal Entity and External Entity. The type of EAI architecture in EMR is as a point to point, the system communicates directly with other systems.

\section{REFERENCES}

[1] M. Subarkah, "Republika," 06 November 2018. [Online]. Available:https://republika.co.id/berita/konsultasi/dokter-kita/ 18/11/06/phqwp3385-rekam-medis-elektronik-big-data-untuk -semua-orang.[Accessed 02 November 2019].

[2] T. Siarif, "Kompasiana," 06 April 2019. [Online]. Available: http://www.kompasiana.com/tammysiarif/5ca843b195760e05 3b3889f2/legalitas-rekam-medis-elektronik?page=all. [Access ed 10 November 2019].

[3] Ministry of Health of the Republic Indonesia, "(In Journal Siswati,\& Dindasari, D. A. (2006). Tinjauan Aspek Keamanan dan Kerahasiaan Rekam Medis di Rumah Sakit Setia Mitra Jakarta Selatan," Jurnal Rekam Medis dan Informasi Kesehatan, vol. 2, no. 2, pp. 91-99, 2019.

[4] Sudjana, "Aspek Hukum Rekam Medis Atau Rekam Medis Elektronik Sebagai Alat Bukti Dalam Transaksi Terapeutik, " Jurnal Rekam Medis dan Informasi Kesehatan,vol. 2, no. 2, pp. 91-99, 2017. https://doi.org/10.25123/vej.2685

[5] PT. BUANA VARIA KOMPUTAMA, "Membangun implementasi rekam medik elektronik EMR terintegrasi di rumah sakit," PT. BUANA VARIA KOMPUTAMA, [Online]. Available:http://www.bvk.co.id/artikel/berita/159-membangu n-implementasi-rekam-medik-elektronik-EMR-terintegrasi-di -rumah-sakit. [Accessed 28 Oktober 2019].

[6] Y. Y. S. \&. S. D. S. Masuda, "Adaptive Governance on Electronic Health Record in a Digital IT era., " in Americas Conference on Information Systems (pp.1-10). Cancun: Association Information Systems., Americas, 2019. 
Refito Ilham et al., International Journal of Emerging Trends in Engineering Research, 8(2), February 2020, 606 - 610

[7] K. T. M. M. V.\&. S. K. Koumaditis, "A PROPOSITION OF CRITICAL SUCCESS FACTORS INFLUENCING SOA IMPLEMENTATION IN HEALTHCARE, " in European Conference on Information Systems (pp. 1-13).Barcelone: Association for Information Systems, Barcelona, 2012

[8] Sjamsuhidat, "(In Journal Naja, Rancangan Bangun Perangkat Lunak Aplikasi Pelayanan Kesehatan Berbasis Service Oriented Architecture)," Jakarta, 2017.

[9] A. \&. S. D. L. Widiarini, "Line Today," Line, 07 August 2019. [Online].Available:https://today.line.me/id/pc/article/Tiap+R S+di+Indonesia+Akan+Terapkan+Sistem+Medical+Record+ Digital-7ok2QM. [Accessed 10 October 2019].

[10] M. Subarkah, "Republika.co.id," Republik, 06 November 2018. [Online]. Available: https://republika.co.id/berita/konsultasi/ dokter-kita/18/11/06/phqwp3385-rekam-medis-elektronik-big -data-untuk-semua-orang. [Accessed 02 October 2019].

[11] A. \&. K. C. M. Muslim, "Manajemen Rumah Sakit Berbasis Arsitektur Berorientasi Servis (SOA)," in Proceeding PESAT, Jakarta, 2011.

[12] B. Adair, "Selecthub," 19 September 2019. [Online]. Avai lable:https://selecthub.com/medical-software/emr-ehr-sof tware-features-requirements-checklist/. [Accessed 15 October 2019].

[13] F. Dzulfikar, "fadhil network," Wordpress.com, 25 April 2017.[Online].Available:https://fadhilnetwork.wordpress .com/2017/04/25/enterprise-application-integration-defin isi-metode-dan-arsitektur/. [Accessed 01 October 2019].

[14] M. R. H. H. N. H. a. K. J. J. L. M. K. W N Hussein,"A Methodology for Big Data Analytics and IoT-Oriented Transportation," International Journal of Emerging Trends in Engineering Research, "International Journal of Emerging Trends in Engineering Research, vol. 7, no. 11, pp. 449-453, 2019.

https://doi.org/10.30534/ijeter/2019/087112019

[15] G. N. A. a. M. A. Wang, "The Use of Internet of Things and Big Data,"International Journal of Emerging Trends in EngineeringResearch, vol. 7, no. 11, pp. 756-761, 2019. https://doi.org/10.30534/ijeter/2019/047122019

[16] V. P. B. a. D. J. Sastry, "Computing Quality of Navigati on Designed into a WEB-Site," International Journal Of Emerging Trends in Engineering Research,"Interna tional Journal Of Emerging Trends in Engineering Resea rch, vol. 7, no. 11, pp. 466-472, 2019. 